\title{
Pasteur plans to pursue patent suit on virus
}

ThE US Justice Department has told the Institut Pasteur in Paris, where virologist Luc Montagnier discovered the virus that causes acquired immune deficiency syndrome (AIDS), that "there is no case to answer" over the laboratory's complaint that the US National Institutes of Health (NIH) pirated Montagnier's discovery and now profits from it by the sale of AIDS blood tests.

The French laboratory has, however, discovered what could be damning new evidence against $\mathrm{NIH}$, and is now considering placing it before the Washington judge investigating whether NIH used the French-discovered virus for commercial gain, in breach of contract between NIH and the Pasteur.

Nobody disputes that Montagnier sent a sample of serum containing the AIDS virus, which he called LAV, to NIH virologist Robert Gallo in September 1983, but NIH claim that Gallo was unable to propagate LAV, and that he subsequently and independently isolated the virus he called HTLV-III. This and a blood test based upon it were rapidly patented and approved for use. HTLV-III tests are now marketed by five US companies, while the Pasteur's test (Elavia) based on Montagnier's virus is still awaiting US patent approval. This is despite the fact that the Pasteur applied for a patent for LAV and its associated test well before NIH applied for a similar patent for HTLV-III.

Pasteur sources claimed last week that the institute has new evidence, in the form of a letter describing research results, that Gallo's laboratory was making electron micrographs of the LAV virus in December 1983, three months after it was first received in a sample from the Pasteur. If this is confirmed, it would seem to contradict the NIH position that Gallo was unable to propagate LAV, and would strengthen at least the circumstantial evidence that HTLV-III is indeed derived from the French isolate. (HTLV-III and LAV have almost identical genetic sequences, but $\mathrm{NIH}$ have argued that this is merely because both viruses came from the same population of patients in New York.) According to the Pasteur, the letter in question describes December 1983 micrographs as pictures of LAV which indicate that it might be a form of lentivirus.

The electron micrographs in question were taken at the National Cancer Institute's Frederick Cancer Research Center. But Gallo and his colleagues scoff at the idea this consitutes evidence of skuldug- gery. Gallo says the letter, along with all other "evidence", was supplied by his own laboratory to Montagnier. He achieved transient growth (evidenced by the electron microscope observations and reverse transcriptase activity) of the LAV sample supplied by Montagnier in a HUD-78 cell line, but for one week only and in small quantity: subsequent tests showed no evidence of viral replication. Attempts to grow LAV in the high-yielding $\mathrm{H} 9$ cell line were totally unsuccessful.

As for the significance of the timing, Dr Peter Fischinger of the National Cancer Institute points out that virus can be frozen and re-examined later, so the interval between the sample arriving and the date of the electron micrograph means nothing. Fischinger remarked that it would be surprising if Gallo had not made micrographs of his attempts to culture the virus. And on the charge that Gallo's isolate was in some way derived from LAV, Fischinger referred to recent results obtained using cytolitic antibodies that kill cells infected with HTLV-III but not those infected with LAV or other isolates and so establish conclusively a real biological difference between the isolates.

In a further and ironic twist to the tale, the US Food and Drug Administration (FDA) last month approved the Pasteur's Elavia test as safe to use, but because of the lack of a patent, Pasteur sources are now concerned at the possibility of legal action against them if Genetic Systems Inc., the company due to market Elavia in the United States, actually sells any tests. According to the Pasteur, while Elavia lacks an independent patent, the five companies selling tests based on HTLV-III and paying royalties under licence to NIH - could complain that Elavia was a "counterfeit" of the NIH test designed to avoid royalty payments, even though the French say the real case is the reverse.

Meanwhile, Elavia is said to be performing very well in tests at the British Public Health Laboratory in London, with results close to those of the Dutch (Organon) and British (Wellcome) tests approved for use "with flying colours" a few months ago. This may leave Elavia with some room on the British market, but in the United States the primary market in blood banks and hospitals is now thought to be effectively tied up by the five companies whose tests are now approved there. The French test shows fewer "false positives" (false indications that a patient has AIDS antibody) than most of the US tests, thus avoiding expensive follow-up tests, but this may not now be enough to win a market share.

British scientists also have a small interest in Elavia, but their work also threatens to displace whatever toehold the French test may have in the United States. Elavia's technical advantage can be traced to the virus cultivated in a line of white blood cells, the CCRF-CEM line (or CEM for short) of $T$ cells, that does not express certain antigens (HLA class two antigens) that can interfere with the results of blood tests.

The use of the CEM line was developed in London's Institute of Cancer Research. The director, Robin Weiss, says that "we have no claim on the CEM line", but his laboratory does have an agreement with the Pasteur that half of any royalties accruing to the Pasteur from use of the CEM line to prepare AIDS tests would return to Britain.

The Pasteur has made further developments "but we would still expect a proportion of the royalties" Weiss said last week, though "our goal has not been to make money but to develop a reliable test for public health". Weiss's laboratory has however developed its own more rapid test, using a British viral isolate and a completely different (and shorter) analysis technique, "competition assay", distinct from the enzyme-linked immunosorbent assay (ELISA) used by all other tests. This test is the one now approved and marketed by Wellcome in Britain. And according to Weiss, "we have not had one false positive in a million tests". Moreover, since the competition assay is complementary to other techniques, Weiss considers it a good follow-up test to check the results of others.

The conclusion is that whatever the result of the Pasteur's legal action in the United States, any mopping-up of the US market may go not to Genetic Systems and Elavia but to what are now more advanced tests such as Wellcome's, or to second-generation tests, now under development, based on the production of pure AIDS virus antigens by recombinant DNA techniques. It now seems clear that if the Pasteur wants to profit at all from tests for AIDS in the United States, it will have to prove that HTLV-III is derived from that sample of LAV that Montagnier sent Gallo back in 1983, and aim for a fraction of royalties on tests now on the market and derived from HTLV-III

Robert Walgate \& Tim Beardsley

\section{Halley's comet data}

BY agreement with the European, Japanese and Soviet groups, Nature will publish on 15 May the first formal accounts of the data gathered by the four encounters with Halley's comet, together with related US observations. 